\title{
Omvang risicogroepen in Limburg
}

Citation for published version (APA):

Künn, A., \& Poulissen, D. (2018). Omvang risicogroepen in Limburg. ROA. ROA Fact Sheets No. 020 https://doi.org/10.26481/umarof.2018020

Document status and date:

Published: 01/01/2018

DOI:

10.26481/umarof.2018020

Document Version:

Publisher's PDF, also known as Version of record

\section{Please check the document version of this publication:}

- A submitted manuscript is the version of the article upon submission and before peer-review. There can be important differences between the submitted version and the official published version of record.

People interested in the research are advised to contact the author for the final version of the publication, or visit the DOI to the publisher's website.

- The final author version and the galley proof are versions of the publication after peer review.

- The final published version features the final layout of the paper including the volume, issue and page numbers.

Link to publication

\footnotetext{
General rights rights.

- You may freely distribute the URL identifying the publication in the public portal. please follow below link for the End User Agreement:

www.umlib.nl/taverne-license

Take down policy

If you believe that this document breaches copyright please contact us at:

repository@maastrichtuniversity.nl

providing details and we will investigate your claim.
}

Copyright and moral rights for the publications made accessible in the public portal are retained by the authors and/or other copyright owners and it is a condition of accessing publications that users recognise and abide by the legal requirements associated with these

- Users may download and print one copy of any publication from the public portal for the purpose of private study or research.

- You may not further distribute the material or use it for any profit-making activity or commercial gain

If the publication is distributed under the terms of Article $25 \mathrm{fa}$ of the Dutch Copyright Act, indicated by the "Taverne" license above, 


\section{Maastricht University $\$$ ROA}

\section{Omvang risicogroepen in Limburg}

Annemarie Künn

Davey Poulissen

\section{ROA Fact Sheet}

ROA-F-2018/20

Researchcentrum voor Onderwijs en Arbeidsmarkt | ROA Research Centre For Education and the Labour Market / ROA 


\section{Omvang risicogroepen in Limburg}

\section{Snelle feiten en cijfers}

1. Ongeveer een kwart van de 15 tot en met 67 jarige inwoners van Limburg bevindt zich in een risicopositie omdat zij een arbeidsongeschiktheids-, werkloosheids- of bijstandsuitkering ontvangen, of omdat zij inactief zijn op de arbeidsmarkt.

2. Er zijn relatief veel personen in een risicopositie te vinden in de oostelijke en westelijke mijnstreek.

3. 8,5 procent van de Limburgse potentiële beroepsbevolking ontvangt een arbeidsongeschiktheidsuitkering. Dit is beduidend hoger dan landelijk (6,3\%).

4. Er is sprake van een concentratie van gemeentes met een hoog aandeel personen met een werkloosheidsuitkering in de regio NoordLimburg.

5. Het percentage inwoners in een risicopositie is het hoogst in de gemeentes Heerlen (32,9\%), Kerkrade $(31,7 \%)$, Vaals $(30,4 \%)$ en Maastricht (30,0\%).

\section{Inleiding}

Limburg telde eind 2015769.396 inwoners die vallen onder de potentiële beroepsbevolking. ' Dat wil zeggen dat zij, puur gebaseerd op hun leeftijd, actief zouden kunnen zijn op de arbeidsmarkt. Echter, ongeveer één op de vier van deze inwoners zijn uitkeringsafhankelijk of niet actief op de arbeidsmarkt. Hiermee bevinden zij zich in een risicopositie.

In deze factsheet zal inzichtelijk worden gemaakt wat de omvang is van een viertal groepen personen met een risicopositie. ${ }^{2}$ We onderscheiden hierbij drie soorten uitkeringsontvangers: (1) personen met

1 We richten ons hier op de situatie op 31 december 2015 omdat meer recente gegevens niet voor alle belangrijke variabelen beschikbaar zijn. Daarmee kunnen de in deze factsheet gepresenteerde data gezien worden als de nulmeting voor de Sociale Agenda Limburg. De potentiële beroepsbevolking wordt door ons gedefinieerd als alle inwoners in de leeftijd 15 tot en met 67 jaar.

2 De resultaten in deze factsheet zijn gebaseerd op eigen berekeningen door het ROA op basis van niet-openbare microdata van het Centraal Bureau voor de Statistiek (CBS). een arbeidsongeschiktheidsuitkering, (2) personen met een werkloosheidsuitkering, en (3) personen met een bijstandsuitkering. Daarnaast brengen we de omvang van een vierde groep personen in kaart: zij die inactief zijn zonder één (of meerdere) van de hierboven genoemde uitkeringen te ontvangen of initieel onderwijs te volgen. Mensen die de AOW-gerechtigde leeftijd hebben bereikt en mensen die een pensioenuitkering ontvangen worden buiten beschouwing gelaten en worden dus niet als inactief bestempeld. Onder de groep inactieven vallen bijvoorbeeld werklozen zonder recht op een werkloosheids- of bijstandsuitkering en mensen die zorgdragen voor de huishouding of opvoeding van hun kinderen zonder daarnaast te werken.

We geven de absolute en relatieve omvang van deze vier risicogroepen weer voor Limburg in totaal, en voor Noord-, Midden- en Zuid-Limburg. Ter vergelijking laten we de omvang van deze groepen ook zien voor Nederland in totaal, voor de gemeente Rotterdam en voor de provincie Groningen.

Vervolgens gaan we dieper in op de situatie in Limburg. Voor elk van de vier risicogroepen laten we de leeftijds- en man-vrouwverdeling zien. Op die manier wordt inzichtelijk gemaakt of de problemen vooral bij jongeren of ouderen zitten en of er een genderverschil is in de mate waarin de Limburgse bevolking uitkeringsafhankelijk of inactief is. Omdat het toegestaan is om naast het ontvangen van een uitkering te werken, laten we ook zien welk deel van de uitkeringsafhankelijken betaald werk verrichten. Personen die naast het ontvangen van een uitkering werken lopen om verschillende redenen minder risico. Allereerst wordt hun uitkering aangevuld door inkomen uit werk. Daarnaast zijn zij actief op de arbeidsmarkt, waarmee zij participeren in de maatschappij. Ook kan het feit dat zij naast hun uitkering werken de kans op uittreding uit uitkeringsafhankelijkheid vergroten.

Ook binnen Limburg zijn er aanzienlijke verschillen in de mate van uitkeringsafhankelijkheid en inactiviteit. Daarom laten we voor alle Limburgse gemeentes zien welk deel van de potentiële beroepsbevolking een arbeidsongeschiktheids-, werkloosheids-, of bijstandsuitkering ontvangt of inactief is. Op deze manier kunnen Limburgse gemeentes onderling 


\section{Fact sheet}

ROA-F-2018/20

vergeleken worden. Deze factsheet draagt bij aan het inzichtelijk maken van de omvang van de in Limburg wonende uitkeringsafhankelijken en inactieven zonder uitkering. Het zegt echter nog niks over wie deze personen zijn en hoe kansarm of kansrijk hun situatie is: hoe is hun gezondheid, wat voor opleiding hebben ze genoten, wat is hun financiële en gezinssituatie, in wat voor wijk wonen zij en wat is hun (specifieke) rol op de arbeidsmarkt? In een volgende factsheet zullen we deze verschillende aspecten van de problematiek van de Limburgers behorende tot de risicogroepen in kaart brengen. Er zal dan bovendien voor alle Limburgse gemeentes worden aangegeven welk deel van de kansarme bevolking ook daadwerkelijk ondersteund wordt door een sociale uitkering. $\mathrm{Er}$ kunnen immers regionale verschillen zijn in de mate waarin kansarme groepen worden ondersteund door het socialezekerheidsstelsel.

\section{Omvang van risicogroepen in Limburg en vergelijkbare regio's}

Tabel 1 geeft een overzicht van de omvang van de hiervoor besproken risicogroepen in Limburg en enkele benchmark regio's op basis van hun uitkeringsafhankelijkheid.

\section{Totaal aantal personen met een risicopositie}

Tabel 1 geeft allereerst een beeld van het totaal aantal personen dat zich in een risicopositie bevindt. Deze aantallen hebben betrekking op personen die ofwel afhankelijk zijn van (minimaal) één van de drie uitkeringstypes ofwel inactief zijn volgens de hierboven genoemde definitie. ${ }^{3}$ Uit de tabel blijkt dat in de provincie Limburg ongeveer een kwart van de personen $(24,9 \%)$ in de leeftijdscategorie 16-67 jaar zich in een risicopositie bevindt op basis van hun uitkeringsafhankelijkheid of inactiviteit. In Limburg is het aandeel mensen in een risicopositie daarmee iets hoger dan landelijk (22,0\%). Alleen in Noord-Limburg ligt het totaal aandeel mensen in een risicopositie met 21,2 procent iets onder het landelijk gemiddelde. MiddenLimburg scoort met 22,5 procent iets boven het landelijk

3 De aantallen in deze kolom wijken af van de optelsom van de afzonderlijke uitkeringen en het aantal inactieven in de tabel omdat individuen tegelijkertijd meerdere uitkeringen kunnen ontvangen. gemiddelde. Het percentage mensen in een risicopositie is het hoogst in Groningen (24,6\%), Zuid-Limburg ( $27,5 \%)$ en Rotterdam (29,7\%).

\section{Personen met een arbeidsongeschiktheidsuitkering}

In Limburg ontving 8,5 procent van de personen in de leeftijdscategorie 15 tot en met 67 jaar op 31 december 2015 een arbeidsongeschiktheidsuitkering. Dit is aanzienlijk hoger dan het landelijke gemiddelde van 6,3 procent. Binnen de provincie Limburg is dit percentage het hoogst in Zuid-Limburg (9,6\%) en het laagst in Noord-Limburg (6,5\%). Midden-Limburg vormt met 7,8 procent de middenmoot. Daarmee is het percentage personen met een arbeidsongeschiktheidsuitkering in alle drie de Limburgse regio's, maar met name in de regio's Midden en Zuid, hoger dan het landelijk gemiddelde. Ook is het percentage personen met een arbeidsongeschiktheidsuitkering in alle drie de Limburgse regio's aanzienlijk hoger dan in de gemeente Rotterdam ( $5,7 \%)$ en dan in de provincie Groningen (7,0\%).

\section{Personen met een werkloosheidsuitkering}

Het aandeel personen met een werkloosheidsuitkering in Limburg is met 3,6 procent iets hoger dan het landelijk gemiddelde (3,3\%). In tegenstelling tot de arbeidsongeschiktheidsuitkeringen, is het percentage werkloosheidsuitkeringen het hoogst in de regio Noord-Limburg $(4,2 \%)$ en juist het laagst in de regio Zuid-Limburg (3,3\%), waar het aandeel personen met een dergelijke uitkering gelijk is aan het landelijk gemiddelde. In beide benchmark regio's ligt het percentage werkloosheidsuitkeringen ongeveer op het gemiddelde voor de provincie Limburg.

\section{Personen met een bijstandsuitkering}

Het aandeel bijstandsontvangers varieert sterk tussen de verschillende regio's. Ook bij dit uitkeringstype is het percentage personen dat hier in Limburg gebruik van maakt $(4,4 \%)$ vergelijkbaar met het landelijke gemiddelde (4,3\%). Binnen Limburg is het percentage bijstandsontvangers het hoogst in Zuid-Limburg $(5,1 \%)$. Het percentage bijstandsontvangers in Noorden Midden-Limburg ontwijken elkaar niet veel met respectievelijk 3,6 procent en 3,4 procent en liggen 


\section{Omvang risicogroepen in Limburg}

TABEL 1.

Overzicht van de absolute en relatieve omvang van de risicogroepen in Limburg en in twee benchmark regio's

\begin{tabular}{|c|c|c|c|c|c|c|}
\hline & $\begin{array}{l}\text { Totaal aantal mensen } \\
\text { in een risicopositie }\end{array}$ & $\begin{array}{l}\text { Arbeids- } \\
\text { ongeschiktheids- } \\
\text { uitkering }\end{array}$ & $\begin{array}{l}\text { Werkloosheids- } \\
\text { uitkering }\end{array}$ & Bijstands-uitkering & $\begin{array}{l}\text { Inactief zonder } \\
\text { uitkering }\end{array}$ & $\begin{array}{c}\text { Potentiële } \\
\text { beroepsbevolking }\end{array}$ \\
\hline \multirow[t]{2}{*}{ Limburg totaal } & 191.493 & 65.022 & 27.527 & 33.667 & 67.411 & 769.396 \\
\hline & $(24,9 \%)$ & $(8,5 \%)$ & $(3,6 \%)$ & $(4,4 \%)$ & $(8,8 \%)$ & \\
\hline \multirow[t]{2}{*}{ Noord-Limburg } & 40.674 & 12.576 & 8.069 & 6.934 & 13.537 & 192.277 \\
\hline & $(21,2 \%)$ & $(6,5 \%)$ & $(4,2 \%)$ & $(3,6 \%)$ & $(7,0 \%)$ & \\
\hline \multirow[t]{2}{*}{ Midden-Limburg } & 36.387 & 12.613 & 5.732 & 5.428 & 13.007 & 161.438 \\
\hline & $(22,5 \%)$ & $(7,8 \%)$ & $(3,6 \%)$ & $(3,4 \%)$ & $(8,1 \%)$ & \\
\hline \multirow[t]{2}{*}{ Zuid-Limburg } & 114.432 & 39.833 & 13.726 & 21.305 & 40.867 & 415.681 \\
\hline & $(27,5 \%)$ & $(9,6 \%)$ & $(3,3 \%)$ & $(5,1 \%)$ & $(9,8 \%)$ & \\
\hline \multirow[t]{2}{*}{ Rotterdam } & 133.325 & 25.508 & 16.356 & 45.649 & 47.029 & 449.506 \\
\hline & $(29,7 \%)$ & $(5,7 \%)$ & $(3,6 \%)$ & $(10,2 \%)$ & $(10,5 \%)$ & \\
\hline \multirow[t]{2}{*}{ Provincie Groningen } & 101.263 & 28.631 & 14.227 & 24.526 & 35.024 & 411.750 \\
\hline & $(24,6 \%)$ & $(7,0 \%)$ & $(3,5 \%)$ & $(6,0 \%)$ & $(8,5 \%)$ & \\
\hline \multirow[t]{2}{*}{ Nederland totaal } & 2.572 .531 & 735.060 & 387.389 & 507.187 & 968.802 & 11.704 .796 \\
\hline & $(22,0 \%)$ & $(6,3 \%)$ & $(3,3 \%)$ & $(4,3 \%)$ & $(8,3 \%)$ & \\
\hline
\end{tabular}

Bron: ROA, berekeningen op basis van microdata van het CBS

daarmee onder het landelijk gemiddelde. In Rotterdam is het percentage bijstandontvangers met 10,2 procent veruit het grootst. Ook in de provincie Groningen is het percentage bijstandontvangers met 6,o procent hoger dan in de drie Limburgse regio's.

\section{Inactieve personen}

8,7 procent van de Limburgers is inactief op de arbeidsmarkt. Zoals eerder aangegeven gaat het hierbij om mensen die inactief zijn zonder één (of meerdere) van de hierboven genoemde uitkeringen te ontvangen of initieel onderwijs te volgen. Mensen die de AOW-gerechtigde leeftijd hebben bereikt en mensen die een pensioenuitkering ontvangen worden buiten beschouwing gelaten en worden niet als inactief bestempeld. Het landelijke percentage inactieven is met 8,3 procent slechts 0,4 procentpunt lager. Binnen de provincie is het aandeel inactieven met 9,8 procent het hoogst in Zuid-Limburg en het laagst in Noord-Limburg $(7,0 \%)$. In Rotterdam is het percentage inactieven met 10,5 procent hoger dan in de drie Limburgse regio's. In de provincie Groningen is het percentage inactieven met 8,5 procent vergelijkbaar met dat van Limburg.

\section{Inwoners met een arbeidsongeschiktheidsuitkering}

De provincie Limburg telde op 31 december 2015 65.022 personen die afhankelijk waren van een arbeidsongeschiktheidsuitkering. Dit is 8,5 procent van het aantal 15 - tot en met 67-jarige inwoners in de provincie.

Mate van arbeidsongeschiktheid onder personen met een arbeidsongeschiktheidsuitkering

Het UWV bepaalt voor arbeidsongeschikten tot welke arbeidsongeschiktheidsklasse men behoort. Een UWV-arts en een arbeidsdeskundige kijken hiervoor naar de verdiencapaciteit van een arbeidsongeschikte. Zij vergelijken hierbij het inkomen dat de arbeidsongeschikte kan verdienen indien er géén sprake zou zij van (gedeeltelijke) arbeidsongeschiktheid met het inkomen dat de arbeidsongeschikte kan verdienen mét zijn of haar ziekte of handicap. Het verschil daartussen bepaalt de arbeidsongeschiktheidsklasse. Vanaf een arbeidsongeschiktheidspercentage van 15 


\section{Fact sheet}

ROA-F-2018/20

procent kan een arbeidsongeschikte aanspraak maken op een arbeidsongeschiktheidsuitkering. ${ }^{4}$

Figuur 1 geeft voor de Limburgers met een arbeidsongeschiktheidsuitkering weer tot welke arbeidsongeschiktheidsklasse zij behoren. Meer dan acht op de tien ontvangers van een arbeidsongeschiktheidsuitkering $(83,1 \%)$ zijn voor ten minste 80 procent arbeidsongeschikt. Zij behoren tot de zwaarste categorie arbeidsongeschikten. Slechts 16,5 procent van alle mensen met een arbeidsongeschiktheidsuitkering vallen in de overige zes klassen. Zoals de figuur toont, verschilt de omvang van deze zes klassen niet veel van elkaar. De percentages schommelen tussen de 1,9 procent voor mensen die voor 55 tot 65 procent arbeidsongeschikt zijn tot 3,4 procent voor mensen die 35 tot 45 procent arbeidsongeschikt zijn. In combinatie met het relatief hoge percentage mensen met een arbeidsongeschiktheidsuitkering in Limburg, illustreren deze cijfers de ernst van de arbeidsongeschiktheidsproblematiek in Limburg.

Het percentage arbeidsongeschikten dat tot de zwaarste arbeidsongeschiktheidsklasse behoort blijkt regionaal enigszins te variëren. Op landelijk niveau $(80,2 \%)$ is het percentage arbeidsongeschikten dat tot de zwaarste arbeidsongeschiktheidsklasse behoort bijvoorbeeld iets lager dan in Limburg. Maar ook binnen Limburg zijn er verschillen waar te nemen: in Zuid-Limburg is het percentage arbeidsongeschikten dat tot de zwaarste arbeidsongeschiktheidsklasse het hoogst (85,3\%) en in Noord-Limburg juist het laagst $(77,7 \%)$. In vergelijking met Limburg blijkt het percentage arbeidsongeschikten dat tot de zwaarste arbeidsongeschiktheidscategorie behoort iets hoger te liggen in Groningen (83,9\%) en juist iets lager in de gemeente Rotterdam $(81,1 \%)$.
FIGUUR 1.

Omvang van arbeidsongeschiktheidsklassen in Limburg
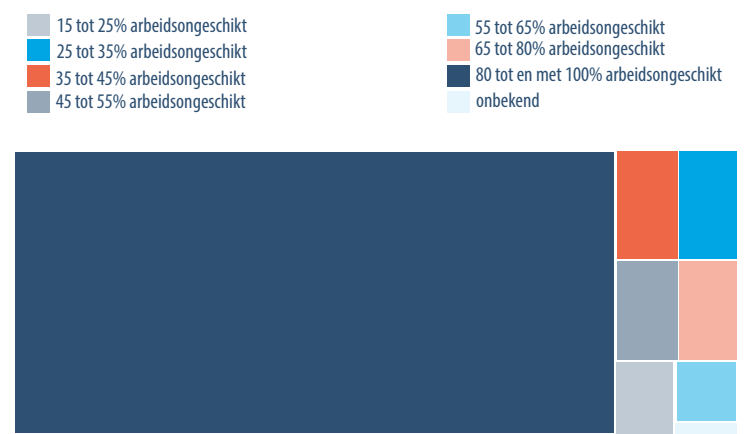

Bron: $\mathrm{ROA}$, berekeningen op basis van microdata van het CBS

\section{Inwoners met een arbeidsongeschiktheidsuitkering naar leeftijd en geslacht}

Figuur 2 laat zien dat van de Limburgers met een arbeidsongeschiktheidsuitkering 50,9 procent man is en 49,1 procent vrouw. Zowel onder mannen als onder vrouwen neemt het aantal arbeidsongeschikten toe met het oplopen van de leeftijd: de meeste arbeidsongeschikten zitten in de hoogste leeftijdscategorie van 54 tot en met 67 jaar; de kleinste groep in de jongste leeftijdscategorie (15 tot en met 27 jaar). De balkjes in de figuur vormen daardoor als het ware een omgekeerde piramide.

Op basis van Tabel 1 was al duidelijk dat er in Limburg relatief veel meer mensen zijn met een arbeidsongeschiktheidsuitkering (8,5\%) dan gemiddeld in Nederland (6,3\%). Het feit dat de Limburgse bevolking iets meer vergrijsd is dan de totale Nederlandse bevolking vormt, in combinatie met het feit dat ouderen iets vaker een arbeidsongeschiktheidsuitkering ontvangen, ${ }^{5}$ een gedeeltelijke verklaring voor het relatief hoge percentage mensen met een arbeidsongeschiktheidsuitkering in Limburg.

5 Zie ook https://www.cbs.nl/nl-nl/nieuws/2016/27/ vergrijzing-meest-toegenomen-in-limburg
4 Zie https://www.rijksoverheid.nl/onderwerpen/wia/vraagen-antwoord/wia-bepaling-mate-van-arbeidsongeschiktheid 


\section{Omvang risicogroepen in Limburg}

FIGUUR 2.

Leeftijds- en man-vrouwverdeling van Limburgers met een arbeidsongeschiktheidsuitkering

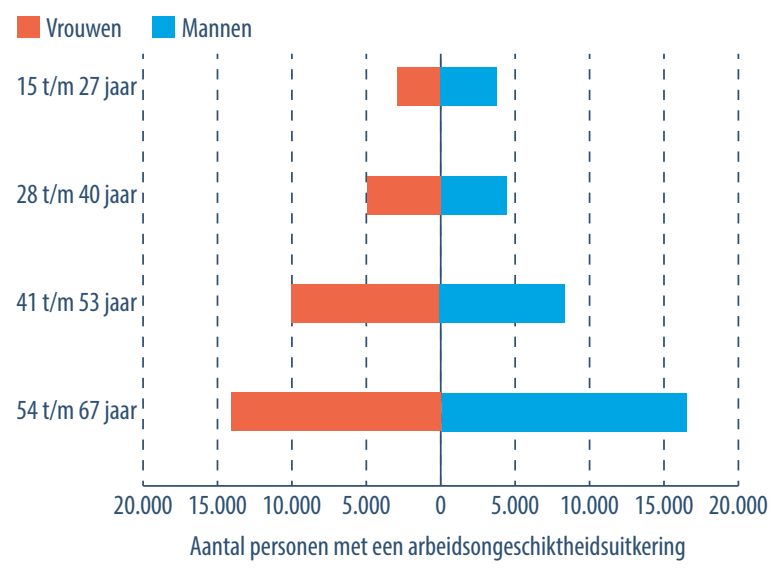

Bron: ROA, berekeningen op basis van microdata van het CBS

Percentage werkenden onder de mensen met een arbeidsongeschiktheidsuitkering

Van de Limburgers met een arbeidsongeschiktheidsuitkering is 17,4 procent ook actief op de arbeidsmarkt als werknemer of zelfstandige. Zij ontvangen naast hun uitkering dus ook inkomen uit werk. Het feit dat zij op de arbeidsmarkt participeren geeft aan dat zij niet geheel aan de zijlijn staan, maar dat zij participeren in de maatschappij.

Lokale verschillen in het percentage inwoners met een arbeidsongeschiktheidsuitkering

Figuur 3 geeft een overzicht van het percentage mensen met een arbeidsongeschiktheidsuitkering in de verschillende Limburgse gemeentes. Enkele gemeentes in de oostelijke en westelijke mijnstreek springen er vanwege het hoge percentage inwoners met een arbeidsongeschiktheidsuitkering meteen uit. In de gemeente Heerlen is het percentage inwoners met een arbeidsongeschiktheidsuitkering met 11,9 het hoogst van alle Limburgse gemeentes. Ook in de gemeentes Kerkrade (11,8\%), Brunssum (11,5\%), Landgraaf $(11,2 \%)$ en Sittard-Geleen $(10,7 \%)$ ontvangt meer dan een op de tien inwoners een arbeidsongeschiktheidsuitkering. Dit is fors hoger dan het landelijk gemiddelde van 6,3 procent. Hoewel de meeste gemeentes met een relatief hoog percentage inwoners met een arbeidsongeschiktheidsuitkering in Zuid-Limburg liggen, zijn er in Zuid-Limburg toch drie gemeentes die tot de tien Limburgse gemeentes met het laagste percentage inwoners met een arbeidsongeschiktheidsuitkering behoren. Het betreft de gemeentes Eijsden-Margraten (6,1\%), Vaals $(6,6 \%)$ en Voerendaal $(6,7 \%)$. De meeste gemeentes met een laag percentage inwoners met een arbeidsongeschiktheidsuitkering liggen in Noord-Limburg. In de gemeente Mook en Middelaar is het percentage inwoners met een arbeidsongeschiktheidsuitkering het laagst van heel Limburg (5\%).

FIGUUR 3.

Percentage inwoners met een

arbeidsongeschiktheidsuitkeringen naar Limburgse gemeente

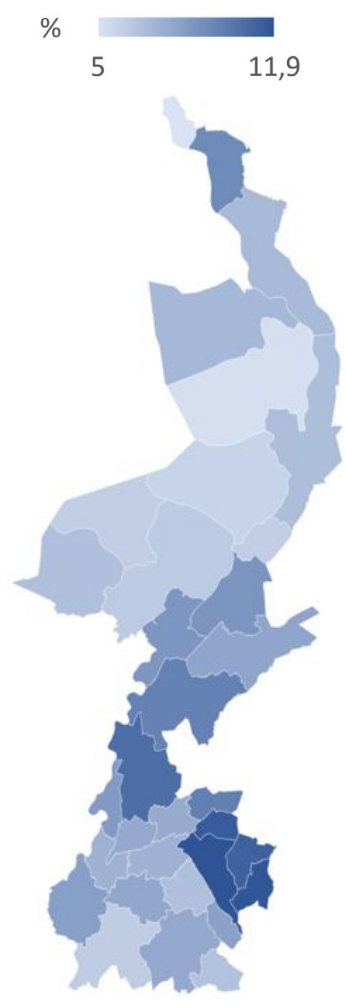

Bron: ROA, berekening op basis van microdata van het CBS

\section{Inwoners met een WW-uitkering}

De provincie Limburg telde op 31 december 2015 27.527 inwoners die een werkloosheidsuitkering ontvangen. 


\section{Fact sheet}

ROA-F-2018/20

Dit is 3,6 procent van het aantal 15- tot en met 67-jarige inwoners in de provincie.

\section{Aantal personen met een werkloosheidsuitkering naar} leeftijd en geslacht

\section{FIGUUR 4.}

Leeftijds- en man-vrouwverdeling van Limburgers met een werkloosheidsuitkering

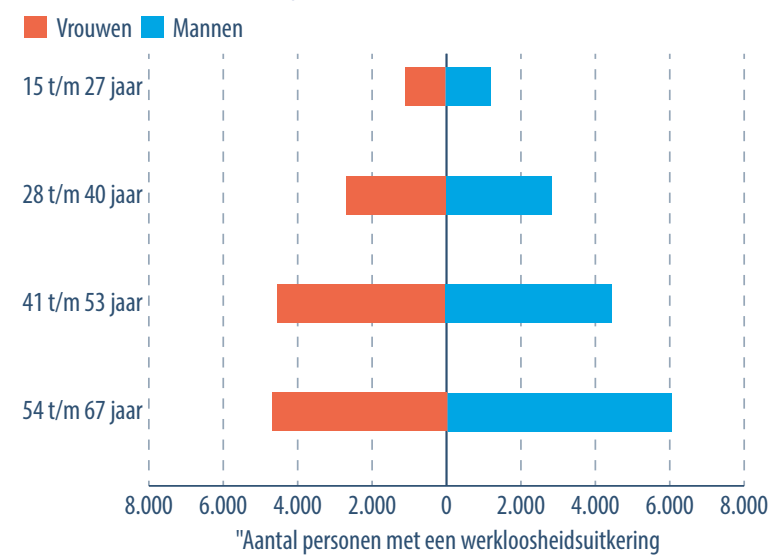

Bron: ROA, berekening op basis van microdata van het CBS

\section{Percentage werkenden onder personen met een werkloosheidsuitkering}

Van de Limburgers met een werkloosheidsuitkering werkt 45,8 procent. Zij vullen hun werkloosheidsuitkering dus aan door in beperkte mate werkzaam te zijn. Zij lijken zich daardoor minder in een risicopositie te bevinden dan werkloosheidsuitkeringsontvangers die geen aanvullend inkomen uit werk hebben.

Lokale verschillen in het percentage inwoners met een werkloosheidsuitkering

Figuur 5 geeft een overzicht van het percentage inwoners met een werkloosheidsuitkering in alle Limburgse gemeentes. De figuur laat een heel ander beeld zien dan bij de arbeidsongeschiktheidsuitkeringen: er is sprake van een concentratie van gemeentes met een relatief hoog percentage inwoners met een werkloosheidsuitkering in de regio Noord-Limburg. De gemeente Venlo kent het hoogste percentage inwoners met een werkloosheidsuitkering (4,5\%), op de voet gevolgd door
Venray (4,2\%), Horst aan de Maas (4,1\%) en Weert (4,1\%). Pas daarna volgt de eerste gemeente uit Zuid-Limburg, namelijk Voerendaal, met 4 procent.

\section{FIGUUR 5.}

Percentage inwoners met een werkloosheidsuitkering naar Limburgse gemeente

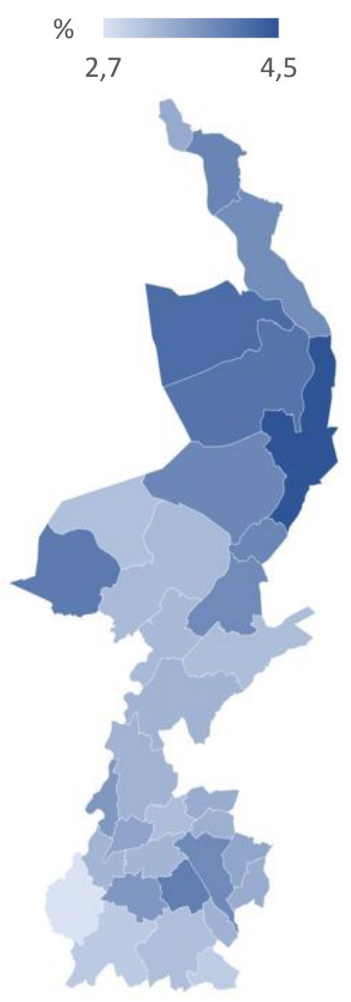

Bron: $\mathrm{ROA}$, berekening op basis van microdata van het CBS

\section{Inwoners met een bijstandsuitkering}

Op 31 december 2015 ontvingen 33.667 Limburgers een bijstandsuitkering. Dit is 4,4 procent van het totaal aantal 15 - tot en met 67 -jarigen.

\section{Aantal personen met een bijstandsuitkering naar leeftijd en geslacht}

Figuur 6 geeft een overzicht van het aantal bijstandsontvangers naar leeftijd en geslacht. Van de mensen met een bijstandsuitkering is 45,7 procent man en 54,3 procent vrouw. Hiermee is dit uitkeringstype het enige van de drie waar vrouwen licht in de meerderheid 


\section{Omvang risicogroepen in Limburg}

zijn. Net als bij de arbeidsongeschiktheids- en werkloosheidsuitkeringen zijn er zowel bij de mannen als de vrouwen meer uitkeringsontvangers in de oudere leeftijdsgroepen dan in de jongere. Opvallend is echter wel dat het aantal mannen of vrouwen met een bijstandsuitkering onder 54- tot en met 67-jarigen weinig verschilt van het aantal mannen of vrouwen met een bijstandsuitkering onder de 41- tot en met 53-jarigen. Dit terwijl we bij de andere uitkeringstypes zagen dat het aantal met elke hogere leeftijdscategorie duidelijk toenam.

\section{FIGUUR 6.}

Leeftijds- en man-vrouwverdeling van Limburgers met een bijstandsuitkering

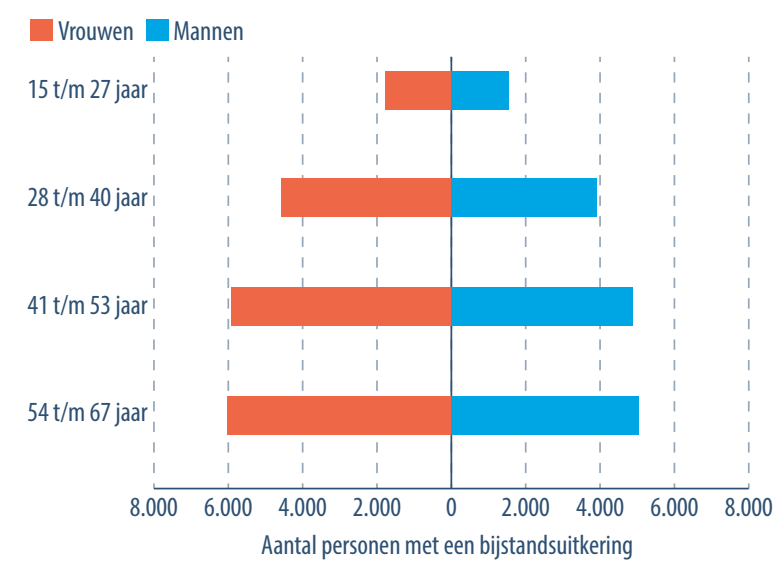

Bron: ROA, berekening op basis van microdata van het CBS

Percentage werkenden onder mensen met een bijstandsuitkering

Van de Limburgers met een bijstandsuitkering heeft 10,9\% werk. Dit is fors lager dan bij de mensen met een werkloosheidsuitkering $(45,8 \%)$, maar ook lager dan onder de mensen met een arbeidsongeschiktheidsuitkering (17,4\%). De mensen met een bijstandsuitkering hebben dus vaker een grotere afstand tot de arbeidsmarkt dan de mensen met een arbeidsongeschiktheids- of werkloosheidsuitkering.

\section{Lokale verschillen in het percentage inwoners met een} bijstandsuitkering

Figuur 7 geeft een overzicht van het percentage inwoners met een bijstandsuitkering in de verschillende Limburgse gemeentes. Terwijl de gemeenten met een hoog percentage inwoners met een arbeidsongeschiktheidsuitkering voornamelijk in de oostelijke en westelijke mijnstreek liggen, en de gemeentes met een hoog percentage inwoners met een werkloosheidsuitkering in Noord-Limburg liggen, lijkt er veel minder sprake te zijn van een regionale clustering van gemeentes met een hoog percentage inwoners met een bijstandsuitkering. In de oostelijke mijnstreek hebben een aantal gemeentes een hoog percentage inwoners met een bijstandsuitkering: Heerlen (8,8\%), Kerkrade (7,2\%) en Brunssum (5,7\%). Dit zijn ook de drie Limburgse gemeentes zijn met het hoogste percentage inwoners met een bijstandsuitkering. Ook is het percentage inwoners dat een bijstandsuitkering ontvangt relatief hoog in de grotere steden van Limburg, waaronder Venlo (5,6\%), Roermond (5,5\%), SittardGeleen (5,3\%) en Maastricht (5,2\%). Weert vormt hierop een uitzondering; het percentage bijstandsontvangers is slechts 3,7 procent. Enkele kleinere gemeentes waar het percentage inwoners met een bijstandsuitkering hoog is zijn Vaals (5,3\%) en Landgraaf (5,0\%).

FIGUUR 7.

Percentage inwoners met een bijstandsuitkering naar Limburgse gemeente

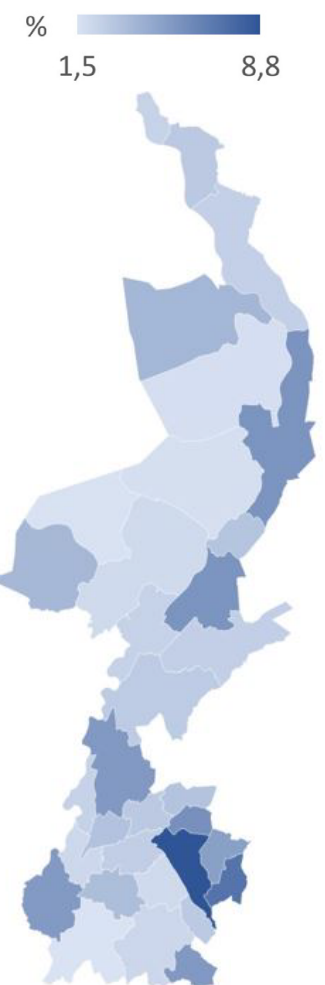

Bron: ROA, berekening op basis van microdata van het CBS 


\section{Fact sheet}

ROA-F-2018/20

\section{Inactieve inwoners die geen uitkering ontvangen of initieel onderwijs volgen}

Limburg telde op 31 december 201567.411 personen in de leeftijd van 15 tot en met 67 jaar die niet actief zijn op de arbeidsmarkt. Deze groep mensen ontvangt dus geen arbeidsongeschiktheids-, werkloosheids-, bijstands-, of pensioenuitkering. Daarnaast staan zij niet ingeschreven in het initieel onderwijs en hebben zij de AOW-gerechtigde leeftijd nog niet bereikt. Dit aantal is gelijk aan 8,8 procent van de potentiële beroepsbevolking in Limburg.

\section{Aantal inactieve personen naar leeftijd en geslacht}

Van de groep inactieven in Limburg is 30,9 procent man en 69,1 procent vrouw. De man-vrouwverhouding verschilt echter enigszins tussen de verschillende leeftijdsgroepen. In de jongste leeftijdsgroep van 15- tot en met 27-jarigen zijn mannen licht in de meerderheid (7.279 mannen versus 7.253 vrouwen), maar voor alle oudere leeftijdsgroepen maken vrouwen duidelijk de meerderheid uit. Bovendien neemt het percentage vrouwen duidelijk toe met het oplopen van de leeftijd.

Het aantal inactieven dat geen uitkering ontvangt of initieel onderwijs volgt is het grootst onder de oudste leeftijdsgroep (54- tot en met 67-jarigen). Dit is te wijten aan het grote aantal inactieve vrouwen in die leeftijdscategorie en is waarschijnlijk deels te verklaren door de relatief lage arbeidsparticipatie van vrouwen in dit cohort. ${ }^{6}$

\section{FIGUUR 8.}

Leeftijds- en man-vrouwverdeling van Limburgers die inactief zijn op de arbeidsmarkt

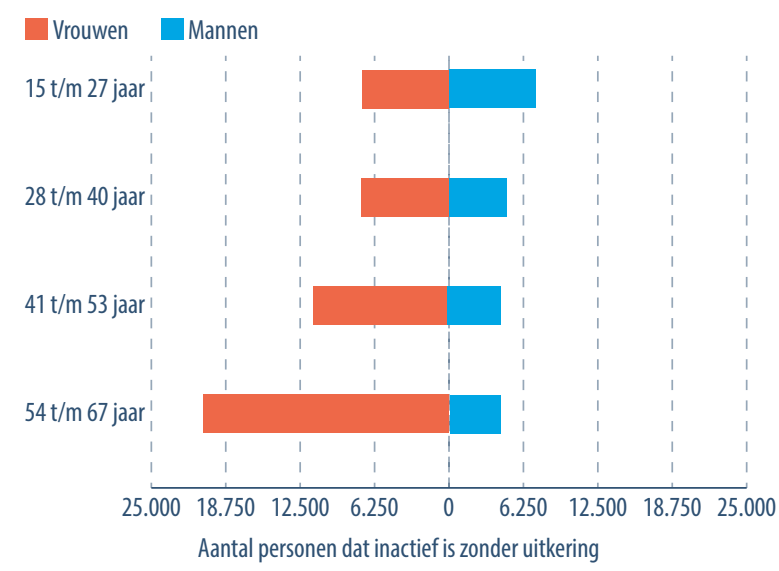

Bron: ROA, berekening op basis van microdata van het CBS

\section{Lokale verschillen in het percentage inactieve inwoners}

Figuur 9 geeft een overzicht van het percentage inactieven dat geen uitkering ontvangt of initieel onderwijs volgt in de verschillende Limburgse gemeentes. Van een duidelijke regionale clustering of clustering in steden is hier geen sprake. De gemeente Vaals kent het hoogste percentage inactieve personen $(15,9 \%)$ en de gemeente Horst aan de Maas het laagste percentage (5,5\%). In Figuur 8 zagen we al dat er relatief veel inactieve (vrouwelijke) personen zijn in de leeftijdsgroep 54 tot en met 67 jaar. Dit in combinatie met het feit dat de gemeente Vaals tot de meest vergrijsde gemeentes van Limburg hoort, terwijl de gemeente Horst aan de Maas juist een van de minst vergrijsde gemeentes is, ${ }^{7}$ biedt een verklaring voor de relatief hoge, c.q. lage scores van deze gemeentes.
6 Zie https://www.cbs.nl/nl-nl/achtergrond/2013/44/ perspectief-op-veranderde-levenslopen-leven-leren-enwerken-naar-geboortegeneratie
7 Zie bijvoorbeeld $\mathrm{https}$ ///opendata.cbs.nl/statline/\#/CBS/nl/ dataset/70648ned/table?dl=151FB 


\section{Omvang risicogroepen in Limburg}

FIGUUR 9.

Percentage inactieve inwoners, naar Limburgse gemeente

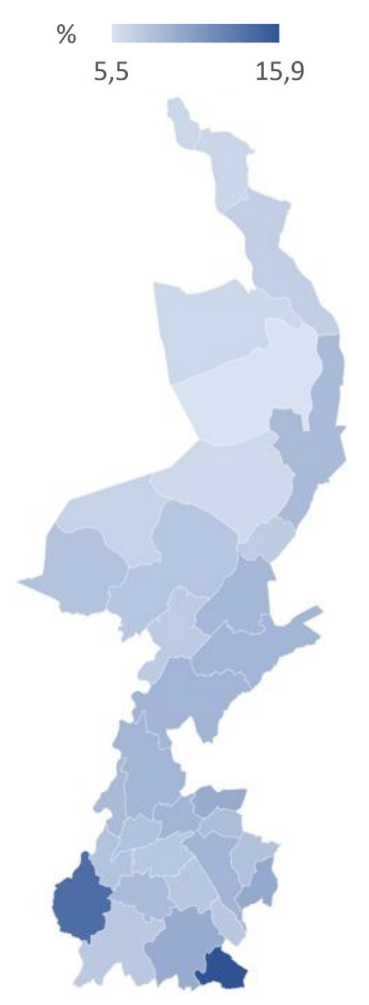

Bron: ROA, berekening op basis van microdata van het CBS

\section{Lokale verschillen in de omvang van de totale groep mensen in een risicopositie}

In deze factsheet hebben we gekeken naar vier groepen inwoners in een risicopositie op de arbeidsmarkt.

Tabel 1 gaf een overzicht van het totaal aantal inwoners dat een arbeidsongeschiktheidsuitkering, werkloosheidsuitkering of bijstandsuitkering ontvangt of inactief is zonder een uitkering te ontvangen of initieel onderwijs te volgen. Figuur 10 geeft een overzicht van de relatieve omvang van de totale groep mensen in een risicopositie in de verschillende Limburgse gemeentes. We zien dat er relatief veel inwoners in een risicopositie zijn in de oostelijke en westelijke mijnstreek. In de gemeente Heerlen is het percentage inwoners in een risicopositie met 32,9 procent het hoogst van heel Limburg. Daarnaast springen in de oostelijke mijnstreek de gemeentes
Kerkrade (31,7\%) en Brunssum (28,5\%) er bovenuit en in de westelijke mijnstreek vooral de gemeente SittardGeleen (27,8\%). De gemeente Maastricht kent met 30 procent ook een relatief hoog percentage inwoners in een risicopositie, net als de minder dicht bevolkte gemeente Vaals $(30,4 \%)$.

De gemeentes met relatief gezien het minste aantal inwoners in een risicopositie liggen voornamelijk in Noord-Limburg. Van de tien Limburgse gemeentes met het kleinste percentage inwoners in een risicopositie, liggen vijf gemeentes in Noord-Limburg, ${ }^{8}$ twee gemeentes in Midden-Limburg ${ }^{9}$ en drie gemeentes in Zuid-Limburg. ${ }^{10}$

8 Het betreft de gemeentes Horst aan de Maas (16,3\%), Mook en Middelaar (17,1\%), Peel en Maas (17,5\%), Beesel $(20,0 \%)$ en Bergen (20,1\%).

9 Het betreft de gemeentes Nederweert $(17,4 \%)$ en Leudal (18,8\%).

10 Het betreft de gemeentes Eijsden-Margraten (17,9\%), Voerendaal $(20,0 \%)$ en Meerssen (20,4\%). 


\section{Fact sheet}

FIGUUR 10.

Percentage inwoners in een risicopositie naar Limburgse gemeente

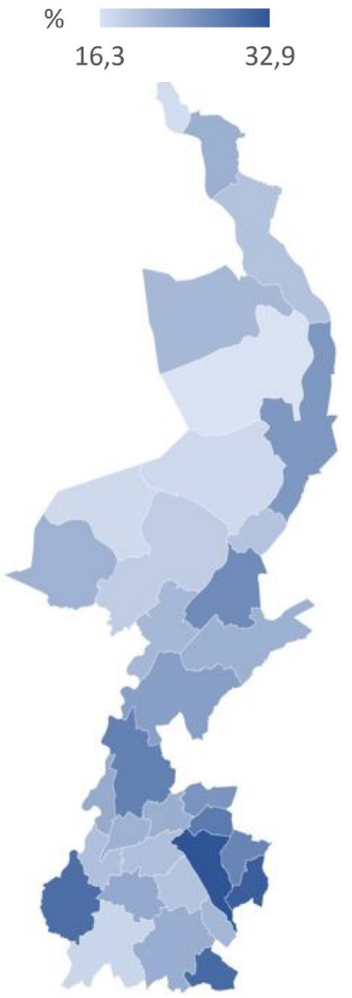

Bron: $\mathrm{ROA}$, berekening op basis van microdata van het CBS 


\section{LIMBURG}

Deze factsheet is een onderdeel van het meerjarenprogramma 4 Limburg dat een bijdrage wil leveren om de Limburgse samenleving meer duurzaam, vitaal en inclusief te maken. Het doel van dit programma is om, in nauwe samenwerking met de Universiteit Maastricht, Provincie Limburg en ketenpartners zoals gemeenten, UWV en bedrijfsleven, via een trendbreuk de arbeidsparticipatie én de vitaliteit in Limburg naar een hoger niveau te tillen. Er zijn in Limburg veel mensen zonder werk onder de potentiële beroepsbevolking. Inzicht in de omvang en complexiteit van de groep uitkeringsontvangers en de groep inactieven die geen uitkering ontvangen en geen initieel onderwijs volgen is nodig alvorens initiatieven kunnen zorgen voor een inclusieve arbeidsmarkt waar iedereen in kan participeren. Deze factsheet heeft als doel de omvang van deze risicogroepen in Limburg in kaart te brengen.

\section{Colofon}

( ) Researchcentrum voor Onderwijs en Arbeidsmarkt Niets uit deze uitgave mag op enige manier worden verveelvoudigd zonder voorafgaande schriftelijke toestemming van de directeur van het ROA.

Researchcentrum voor Onderwijs en Arbeidsmarkt

Maastricht University

School of Business and Economics

secretary-roa-sbe@maastrichtuniversity.n

www.roa.nl

\section{Vormgeving}

ROA secretariaat, Maastricht 